\title{
In Vivo Screening of the Extract of Solenostemon Monstachyus and Ocimum Gratissimum for the Management of Type-2 Diabetes
}

\author{
Ikpesu TO* and Ezenwaka CO \\ Department of Biology, Federal University Otuoke, Nigeria
}

Submission: January 09, 2018; Published: July 16, 2018

*Corresponding author: Ikpesu TO, Department of Biology, Federal University Otuoke, Nigeria, Tel: +2348032312141;

Email: ikpesuto@fuotuoke.edu.ng

\begin{abstract}
The efficacy of synergistic of Solenostemon monostachyus and Ocimum gratissimum for the management of type-2-diabetes using Zebra fish was investigated. The plants were dried, grounded and the powder was pooled together, homogenized and extracted for 7 hours using the Soxhlet apparatus. A total of 75 zebra fish were used and were divided into five groups of five juveniles per test concentration in three replicates. Group A was given de-chlorinated water; B was treated with $0.25 \mathrm{mg} / \mathrm{L}$ diazinon only while other groups were exposed to the same concentration as in group B, but with different concentrations of the plant's extract. Group C, D and E received 250, 500 and 750mg/L respectively. Water quality parameters and blood chemistry were estimated in the experimental and control fish on day 7, 14, 21 and 28th. All the blood parameters were significantly $(<0.05)$ affected by diazinon when compared with the control. But were reversible in the plants extract mixture treated fish and were dose and time dependent reduction, even less than the control group. This finding had shown the efficacy of these plants' extract and the use of zebra fish as toxicological tool. Thus, thorough study of these plants mixture is indispensable, so as to find a lasting solution to the ailment that has been given people a nightmare.
\end{abstract}

Keywords: Solenostemon monstachyus; Ocimum gratissimum; Mixture; Diazinon; Zebra fish; Human

\section{Introduction}

Diabetes is one of the most noxious and precarious ailment that has been a menace to the life of people. The condition is mainly defined by the level of hyperglycemias which gives rise to the risk of micro-vascular damage [1]. Diabetes mellitus is of two types; type I (insulin-dependent), this is when the insulin producing $\beta$-cells are not functioning well therefore no enough insulin production, and type II (noninsulin dependent) caused by relative insulin insufficiency due to insulin resistance-the inability of the insulin to tell the cells to use glucose in addition to insufficient insulin to overcome this resistance. Of a truth diabetes has robbed many people in the past years in living a healthy and normal life [2]. The controls of diabetes depend on the triad of food, activity and insulin or oral agents. All these must be balanced properly by the diabetic patient.

It has been estimates by the World Health Organization (WHO) that over 366 Million people worldwide are affected by diabetes mellitus, and many without efficacious diabetes care [3]. A recent revelation by the WHO indicates that diabetes has tripled in the last two decade globally with the highest prevalence rates found in developing countries [4]. The WHO report indicates that in extreme cases, up to $30-50 \%$ of the adult population in some developing countries have been afflicted with diabetes [4]. Chinenye [5] reported that in Nigeria, with the population of over 180 million people (2006 census), an estimated six million people have full blown diabetes mellitus.

The 1992 National prevalence study on Non-communicable diseases conducted by the Federal Ministry of Health in 13 states of the Federation indicated a prevalence rate of $2.7 \%$ with a prevalence of $2.6 \%$ in adult males and $2.8 \%$ in adult females. Reports from subsequent studies as hospital records indicated an alarming increase in both prevalence and incidence of diabetes among all ethnic groups and social classes in the world [5]. Medicinal plants have been used in many years back to treat diseases all over the world. Some medicinal plants have been proven to be anti-diabetic plants used to treat diabetes mellitus by the local folks. Some of such plants are Solenostemon monostachyus (SM) and Ocimum gratissimum (OG), but have not been examined medically. Therefore, the study was designed to investigate the acclaimed anti-diabetic abilities of the extract mixture of Solenostemon Monostachyus and Ocimum Gratissimum extract macerated in acetone. 


\section{Current Research in Diabetes \& Obesity Journal}

\section{Materials and Methods}

\section{Chemical/Equipment analysis}

Diazinon (98.5\%purity) that was used for fish bioassay was obtained from chemical Service, West Chester, UK, Aquaria (locally built), Aerators from Agro chemicals, Canada, ethyl 3-aminobenzoate methanesulfonate salt, Sigma.

\section{Collection and handling of experimental fish}

The zebra fish used for the test were raised in the laboratory in a well-aerated tarpaulin tank for three months. From the tank, 15 post juveniles' fish weighing $23.20 \pm 0.12 \mathrm{gm}$ and $17.00 \pm 0.13 \mathrm{~cm}$ in length were taken into well-aerated containers, to avoid hyperactivity, injuries and shock. The fish were examined for any pathological sign and washed with $1 \% \mathrm{KMnO} 4$ solution, and transferred to glass aquaria $(50 \times 25 \times 25 \mathrm{~cm})$ containing dechlorinated tap water. They were allowed to acclimatize to their new environment (glass aquaria) conditions for 14 days prior to experiment and were fed with $30 \%$ protein pellets. Water was replaced regularly and immunological parameters of the water were kept within the recommended range with electrical aerators. At the end of the acclimatization, all the fish were in good health and no mortality observed.

\section{Cultivation of the plants ( $S$. monostachyus and $O$. gratissimum)}

A well-drained, sunny location within Federal University Otuoke Nigeria premises earmarked for botanical gardens was used for the cultivation of the herbs. The soil was tested to determine the soil $\mathrm{pH}(6.0-6.8)$ and nutrient levels. Geophysics Department of the University assist in ascertained the physicochemical parameters of the soil. The seeds of $S$. monostachyus and 0 . gratissimum were purchased from the market and cultivated within 2 hours. The plants were monitored and grew into maturity within two months.

\section{Crude extraction}

The fresh leaves of $O$. gratissimum and S. monostachyus were collected from the garden and dried separately at room temperature $(22+0.15){ }^{\circ} \mathrm{C}$ for 21 days in the laboratory. They were grounded separately using Nakai blender and filtered through a 40-mesh screen. They were grounded separately using Nakai blender and filtered through a 40-mesh screen Equal volume $(1.5 \mathrm{~kg})$ each of the two plants powders and were homogenized. The dry powder was extracted by maceration at $35-37{ }^{\circ} \mathrm{C}$; five times for 18 to $20 \mathrm{hrs}$ with $70 \%$ ethanol. Filtered under vacuum and dried using rotary evaporator (Heidolph, Schwabach, Germany) at $35-40{ }^{\circ} \mathrm{C}$. The extract was weighed and preserved aseptically at $4{ }^{\circ} \mathrm{C}$.

\section{Photochemical determination}

The photo-chemical compositions of the plants were analyzed using the methods described by Trease \& Evans [6]. The following chemical composition of the plants leaves were determined quantitatively; Alkaloid, Terpene, Flavonoids, Saponins, Anthraquinones, Tanin, Phlobatanins, Phenol and Cardiac glycoside .

\section{Bioassay test}

The fish were divided into five groups comprising five fish per test concentration. They were exposed to the concentrations of organophosphate that has been experimentally proven to induce hyperglycemias [7], and other treatments as stated below. Group A was given de-chlorinated tap water; B was treated with $0.25 \mathrm{mg} / \mathrm{L}$ diazinon only while other groups were treated to the same concentration as in group B, but with different concentrations of the plants extracts mixture. Group C, D and E received 250,500 , and $750 \mathrm{mg} / \mathrm{L}$ respectively. Water quality parameters were kept within the normal range with the help of aerator. The blood sugar was estimated in the experimental and control fish on day $7,14,21$ and $28^{\text {th }}$.

\section{Blood sugar determination}

At the end of each experimental period (day 7, 14, 21 and $28^{\text {th }}$ ), a fish was removed from each aquarium and immediately anesthetized with MS222 (ethyl 3-aminobenzoate methanesulfonate salt, Sigma). Blood sample was taken by puncturing the caudal vessels with a 20-gauge needle and aspirating $0.2-0.4 \mathrm{~mL}$ sample of mixed arterial and venous blood into a heparinized syringe, a technique shown to minimize dilution by tissue fluids [8]. The blood sample was stored in heparinized blood collecting duct for the estimation of blood sugar level. The blood was allowed to clot for $30 \mathrm{~min}$, centrifuged at $2000 \mathrm{~g}$ for $15 \mathrm{~min}$ for clear separation of the serum, and stored at $-80{ }^{\circ} \mathrm{C}$ until the analysis.

\section{Glucose analysis}

Folin-Wu protein free filtrate was prepared by adding nine volumes of the mixture containing eight parts $\mathrm{N} / 12 \mathrm{H}_{2} \mathrm{SO}_{4}$ and one part of sodium tong state directly to the sera separated from the whole blood [9]. The medium was filtered and the filtrate was taken in a tube and two $\mathrm{ml}$ of alkaline copper sulphate solution was added. The optical density was measured at $420 \mathrm{~nm}$ in a spectrophotometer. Simultaneously, standard glucose solution containing $1 \mathrm{mg} \bullet \mathrm{ml}$ and a blank containing $2 \mathrm{ml}$ distilled water was taken for the observations.

\section{Statistical Analysis}

The data of the efficacy of synergistic of different concentrations of $S$. monstachyus and 0 . gratissimum for the management of type-2-diabetes were presented as mean $\pm S D$, from 5 independent experiments with triplicates. The difference between the control and the various treatments and within the treatments were analyses using the student's t- test at 95\% confidence level [10] and one-way analysis of variance SPSS (14.0 version), SPSS Inc, Chicago, USA. P $\leq 0.05$ was considered to be significant. 


\section{Current Research in Diabetes \& Obesity Journal}

\section{Results}

\section{Hydo-chemical properties of the test media}

The water quality parameters $(\mathrm{pH}$, temperature, dissolved

Table 1: The physiochemical parameters of the test media. oxygen, alkalinity and hardness) monitored during the investigation was not significantly different between various concentrations of the pesticide and the control and within concentrations ( $\mathrm{p}>0.05)$ (Table 1).

\begin{tabular}{|c|c|c|c|c|c|c|}
\hline Parameters & $\mathbf{p H}$ & Temp (OC) & DO (mg/l) & Turbidity (mg/L) & Alkalinity (mg/L) & Hardness (mg/L) \\
\hline Group $(\mu \mathrm{g} / \mathrm{L})$ & Mean \pm SD & Mean \pm SD & Mean $\pm S D$ & Mean $\pm S D$ & Mean $\pm S D$ & Mean $\pm S D$ \\
\hline A & $7.22 \pm 0.02$ & $25.67 \pm 0.16$ & $8.10 \pm 0.22$ & $0.23 \pm 0.04$ & $17.40 \pm 0.72$ & $31.23 \pm 1.15$ \\
\hline B & $7.36 \pm 0.16$ & $25.00 \pm 0.30$ & $8.12 \pm 0.19$ & $0.23 \pm 0.06$ & $17.63 \pm 0.42$ & $31.33 \pm 1.15$ \\
\hline C & $7.25 \pm 0.10$ & $27.33 \pm 0.68$ & $8.30 \pm 0.31$ & $0.24 \pm 0.02$ & $17.40 \pm 0.36$ & $31.20 \pm 1.02$ \\
\hline D & $7.12 \pm 0.25$ & $27.00 \pm 1.20$ & $8.03 \pm 0.22$ & $0.25 \pm 0.04$ & $17.13 \pm 1.20$ & $30.60 \pm 0.50$ \\
\hline E & $7.12 \pm 0.20$ & $26.33 \pm 0.48$ & $8.16 \pm 0.02$ & $0.26 \pm 0.03$ & $17.23 \pm 0.12$ & $30.60 \pm 0.16$ \\
\hline
\end{tabular}

A: Distilled water; B: $0.25 \mathrm{mg} / \mathrm{L}$ diazinon treatment; C: $0.25 \mathrm{mg} / \mathrm{L}$ diazinon and $250 \mathrm{mg} / \mathrm{L}$ equal mixture of crude extract of $S$ monostachyus and $O$ gratissimum; D: $0.25 \mathrm{mg} / \mathrm{L}$ diazinon and $500 \mathrm{mg} / \mathrm{L}$ equal mixture of crude extract of $S$ monostachyus and $O$ gratissimum; $\mathrm{E}$ : with $0.25 \mathrm{mg} / \mathrm{L}$ diazinon and $750 \mathrm{mg} / \mathrm{L}$ equal mixture of crude extract of $S$ monostachyus and $O$ gratissimum.

\section{Phytochemical screening}

The results of the photochemical composition of the leaves extracts of the investigated plants showed the presents of Alkaloid, Terpene, Flavonoids, Saponins, Deoxy-Sugar, Anthraquinones, Tanin, Phlobatanins and Cardiac Glycoside. The magnitude of concentrations of the chemicals in these plant leaves extract differs as represented with depiction (Table 2).

Table 2: Phytochemical compositions of the leaves extracts of S. monostachyus and O. gratissimum.

\begin{tabular}{|c|c|c|}
\hline Phytochemicals & S. monostachyus & O. gratissimum \\
\hline Anthraquinones & $* *$ & $*$ \\
\hline Phenol & $* *$ & \\
\hline Flavonoids & $* * * *$ & $*$ \\
\hline Saponins*** & $*$ & \\
\hline Alkaloid & & $*$ \\
\hline Phlobatanins** & $* *$ & $*$ \\
\hline Terpenes** & $* *$ & $*$ \\
\hline Tannin & $*$ & \\
\hline Cardiac Glycoside & & \\
\hline
\end{tabular}

Keys: *Present in moderately concentration; **Present in high concentrations; $\neq$ Not detected

\section{Blood glucose}

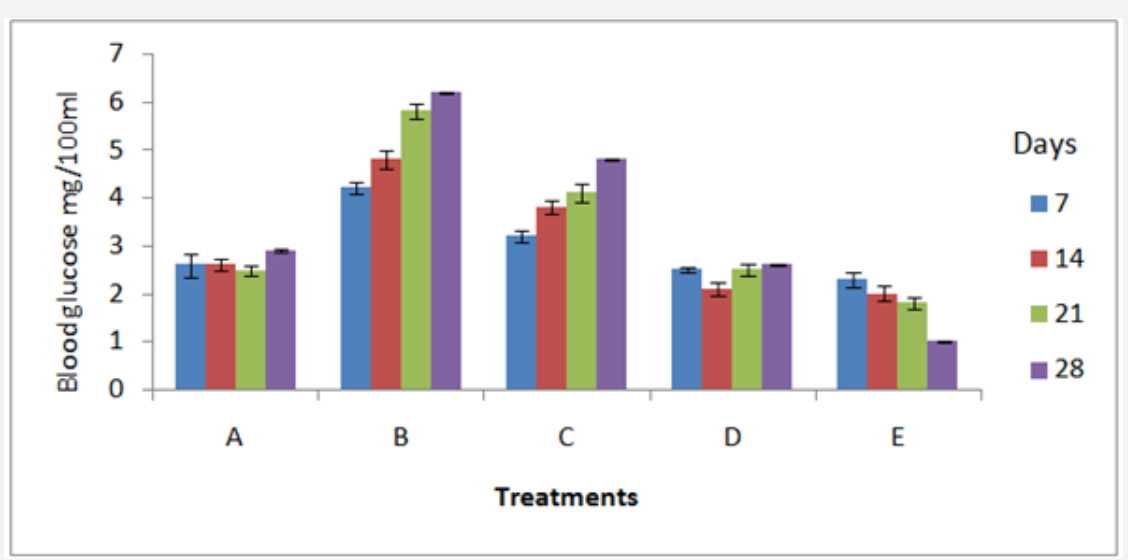

Figure 1: Responses of Zebra fish to different treatments; A: Distilled water; B: $0.25 \mathrm{mg} / \mathrm{L}$ diazinon treatment; C: $0.25 \mathrm{mg} / \mathrm{L}$ diazinon and $250 \mathrm{mg} / \mathrm{L}$ equal mixture of crude extract of $S$ monostachyus and gratissimum O; D: $0.25 \mathrm{mg} / \mathrm{L}$ diazinon and $500 \mathrm{mg} / \mathrm{L}$ equal mixture of crude extract of $\mathrm{S}$ monostachyus and $\mathrm{O}$ gratissimum; $\mathrm{E}$ : with $0.25 \mathrm{mg} / \mathrm{L}$ diazinon and $750 \mathrm{mg} / \mathrm{L}$ equal mixture of crude extract of $\mathrm{S}$ monostachyus and $\mathrm{O}$ gratissimum. 
The responses of the zebra fish to diazinon and to the different concentrations of the synergistic of $S$. monostachyus and 0 . gratissimum is shown in Figure 1. The glucose level in aqueous treated fish (group A) shows no significant difference between the days of exposure ( $p>0.05)$. However, in the diazinon alone treatment, the fish were hyperglycaemic, which increases with exposure duration and varies significantly $(\mathrm{p}<0.05)$. In the treatment $C$, the fish responses is similar to $B$ treated fish but was not significant ( $p>0.05$ ), though the effect of the plant extract was slightly obvious. There was fluctuation in the D treatment, although not significant $(p>0.05)$, but the effects was quite obvious and comparable to the control. E treated fish shows hypoglycaemic as the day's progresses. On day 7 and $14^{\text {th }}$, the sugar level is similar to that of the control, while day 21 and $28^{\text {th }}$, the level was lower than the control, the fish were hypoglycaemic and the variation was highly significant $(\mathrm{p}<0.01)$.

\section{Discussion}

Herbal medicines have played an important role in treating diabetes in various parts of the world for centuries, and their synergistic properties due to the presence of variety of components within herbals extract are beneficial to multifactorial diseases like diabetes [11]. In this investigation, the responses of the hyperglycaemic induced zebra fish to the synergistic of $S$. monostachyus and 0 . gratissimum revealed doses and time dependent recovery, with the concentration of $500 \mathrm{mg} / \mathrm{L}$ plants extracts comparable with the control. When the concentrations of the extracts was increased to $750 \mathrm{mg} / \mathrm{L}$ there was spontaneous decrease in the sugar level, far below the reference value (Figure 1 ) and was highly significant $(\mathrm{p}<0.1)$ on day $28^{\text {th }}$.

This anti-diabetic's property $S$. monostachyus and $O$. Gratissimum may be attributed to the synergistic and the potency of their photochemical compositions. Alkaloid is known to exhibits hypoglycaemic activity and antioxidant properties $[12,13]$. Terpene often refers to as terpenoids has a broad range of the biological properties, including cancer chemo preventive effects, antimicrobial, antifungal, antiviral, ant hyperglycemic, anti-inflammatory, and ant parasitic activities [14]. Saponin is essentially good in glycemic control as well as its principal roles in preventing different metabolic disorders and liver damage caused by hyperglycemias. Its anti-diabetic activity is attributed to its components that plays vital activity in there leasing of insulin from the pancreas that is, it exerts a direct insulin tropic effect [15].

2-hydroxy-3-methyl-anthrqui $\neg$ none is another photochemical component of the investigated plants and was also identified as the hypoglycaemic active components of binate [16]. Although Anthraquinones glycosides have been known to cause diarrhea, aglycone has several other biological activities such as antibacterial and anti-inflammatory effects [16]. Similarly Ye et al. [17] reported that early intervention with Anthraquinones glycosides significantly improved glucose tolerance and restored early-phase insulin secretion in $\mathrm{db} /$ $\mathrm{db}$ mice. Equally, the tannin photochemical observed in $S$. monostachyus and 0 . gratissimum was also reported in extract from the amaranth grain, finger millet, field bean, sunflower seeds, drumstick, and amaranth leaves, and it exerted significant higher antioxidant and anti-diabetic activities [18]. Phenols are known for their anti-hyperglycaemic activity [18], was present in high concentrations in $S$. monostachyus and moderately concentrated in 0 . gratissimum. This agrees with the local uses of the leaves of the plant for the treatment of diabetes by traditional medicine practitioners [19].

\section{Conclusion}

Diabetes mellitus is becoming a threat to world, with the significant achievements in treatment modalities and preventive measures; its prevalence has risen exponentially. Because of these limitations, there is continuous need for new and more effective therapies to combat the surge. The synergistic of $S$. monostachyus and 0 . gratissimum had shown ameliorating effects in the control of hyperglycemias and justify the traditional uses of the plants for the treatment of diabetes.

Further study is necessary to investigate the mechanism behind the hypoglycaemic effect of the synergistic of these two plants. We strongly believe that they are promising anti-diabetic constituents that will be helpful for the management of type 2 diabetes, and stabilize blood sugar level for longer periods.

\section{Funding Information}

The research was part of a Ph.D. thesis, and was selffunded. No specific grant from any funding agency in the public, commercial or not-for-profit sector was received

\section{Acknowledgement}

We appreciate the effort of Mr. Owolabi, the Chief Technologist Department of Biochemistry, Federal University Otuoke, for his unalloyed support in setting the aquaria and analysis of the samples.

\section{Author's Contribution}

Ikpesu TO: Design the research and take part in the writing of the article.

Ezenwak 0: Monitor the fish in the laboratory, collect the blood samples and did all the analysis. She also participated in the writing of the article.

\section{References}

1. Sunil C, Ignacimuthu S, Agastian P (2011) Antidiabetic effect of Symplocos cochinchinensis (Lour.) S. Moore. in type 2 diabetic rats. J Ethnopharmacol 134(2): 298-304.

2. Asanga EE, Ebong PF, Eseyin OA (2013) Hypoglycemic effects of Ethanol extract and the fractions of Nauclea latifolium leaf in normal and alloxan induced diabetic rats. International Journal of Biochemistry and Biotechnology 2(6): 457-460.

3. Riya MP, Antu KA, Vinu T, Chandrakanth KC, Anilkumar KS (2014) An in vitro study reveals nutraceutical properties of Ananas comosus 
(L.) Merrvar. Mauritius residue beneficial to diabetes. J Sci Food Agric 94(5): 943-950.

4. Heim KE, Tagliaferro AR, Bobilya DJ (2002) Flavonoid antioxidants: chemistry, metabolism and structure-activity relationships. J Nutr Biochem 13(10): 572-584.

5. Chinenye S (2015) Diabetes proposal by diabetes association of Nigeria. National Diabetes Centre, Port Harcourt, Nigeria, p. 1.

6. Trease GE, Evans WC (1989) Pharmacognosy. (13 ${ }^{\text {th }}$ edn), ELBS Oxford University Press, London, UK, pp. 245-263.

7. Ikpesu TO, Tongo I, Ariyo A (2014) Restorative prospective of powdered seeds extract of garcinia kola in Chrysichthys furcatus Induced with Glyphosate formulation. Chinese Journal of Biology, pp. 1-8.

8. Congleton JL, La Voie WJ (2001) Comparison of blood chemistry values for samples collected from juvenile Chinook salmon by three methods. Journal of Aquatic Animal Health 13(2): 168-172.

9. Folin, Wu (1926) Determination of blood glucose level. Journal of Biological Chemistry 38: 81.

10. Steel R, Torrie J (1980) Principles and Procedures of Statistics, McGraw Hill, NY, USA, pp. 134-145.

11. Graziose R, Lila MA, Ras kin I (2010) Merging traditional Chinese medicine with modern drug discovery technologies to find novel drugs and functional foods. Curr Drug Discov Technol 7(1): 2-12.

12. Chattopadhyay RR (1999) A comparative evaluation of some blood sugar lowering agents of plant origin. J Ethnopharmacol 67(6): 367372.
13. Singh SF, Vats P, Suri S, Shyam R, Kumria MM, et al. (2001) Effect of an antidiabetic extract of Catharanthus roseus on enzymic activities in streptozotocin induced diabetic rats. J Ethnopharmacol 76(3): 269277.

14. Chen Y, Yang G (2005) Review of the structures and biological activities of phenanthrenes from Junaceae plants. Nat Prod Res Dev 17(4): 505507.

15. Metwally NS, Mohamed AM, Sharabasy FS (2012) Chemical constituents of the Egyptian Plant Anabasis articulate (Forssk) Moq and its anti-diabetic effects on rats with streptozotocin-induced diabetic hepatopathy. J Appl Pharm Sci 2(4): 54-65.

16. Alajmi MF, Alam P (2014) Anti-inflammatory activity and qualitative analysis of different extracts of Maytenus obscura (A. Rich.) Cuf. by high performance thin layer chromatography method. Asian Pac J Trop Biomed 4(2): 152-157.

17. Ye XZ, Du H, Shao JQ (2010) Early effect of rhein on insulin secretion in $\mathrm{db} / \mathrm{db}$ mice. Mod J Integ Tradi Chin West Med 19: 4668-4670.

18. Catherine NK, Jasper KI, Michael O, Clarke M, Han KB, et al. (2011) Antioxidant and Anti-diabetic properties of condensed tannins in acetonic extract of selected raw and processed indigenous food ingredients from Kenya. J Food sci 76(4): 560-567.

19. Simmonds MSJ, Howes MJR (2006) Traditional medicines for modern times: anti-diabetic plants. In: Soumyanath A (Ed.), Taylor and Francis Group, UK.

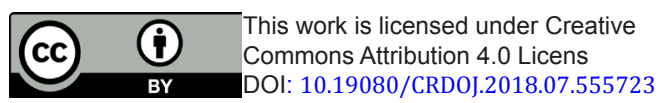

\section{Your next submission with Juniper Publishers} will reach you the below assets

- Quality Editorial service

- Swift Peer Review

- Reprints availability

- E-prints Service

- Manuscript Podcast for convenient understanding

- Global attainment for your research

- Manuscript accessibility in different formats

( Pdf, E-pub, Full Text, Audio)

- Unceasing customer service

Track the below URL for one-step submission https://juniperpublishers.com/online-submission.php 